\title{
Impact of Silicon and Humic Acid Application under Water Stress Condition on some Bread Wheat Cultivars and Some Soil Properties
}

\author{
"El-sayed, M.E.A. ${ }^{1}$; G.M.M. Soliman ${ }^{2}$ and A.F. Ahmed ${ }^{1}$ \\ ${ }^{1}$ Soils, Water and Environmental Research Institute, Agriculture Research Center, \\ El-giza, Egypt. \\ ${ }^{2}$ Field Crops Research Institute, Agriculture Research Center, El-giza, Egypt. \\ "Corresponding author: eid1592003@yahoo.com
}

Received on: 30/12/2018

Accepted for publication on: 2/1/2019

\begin{abstract}
:
Wheat (Triticum aestivum L.) is widely cultivated in the Mediterranean zone where plants generally suffer from water stress during heading and reproductive stages. This research was carried out in a field experiment at Shandaweel Agricultural Research Station during the two successive growing seasons 2015/2016 and 2016/2017 using water treatments (water stress and well watered) and humic acid (soil application) and silicon (foliar application) on some wheat cultivars (Gemmeiza 11, Shandaweel1, and Sids 12). The application rate of humic acid and silicon was $2 \mathrm{Kg} /$ feddan and $150 \mathrm{ppm}$, respectively. The results showed that wheat cultivars had a significant effect on the all studied traits. Normal irrigation gave the highest significant mean values of all studied traits in both seasons. Treatment by silicon or humic acid effected significantly in all the studied traits in both seasons as compared to control treatment. The interaction between irrigation treatments and wheat cultivars were significant or highly significant for most of the studied traits in both seasons. Moreover, under normal irrigation, there are no changes in some chemical and physical properties of soil, however, there are slightly changes in the physical properties of the soil and a significant changes in the chemical properties under water stress condition. Using silicon didn't affect or played any role on soil properties under normal or water stress condition, whereas using humic acid reduced water stress effect on soil properties.
\end{abstract}

Keywords: Humic acid, Silicon, Wheat, Water stress, Soil properties.

\section{Introduction}

Water stress is the main factor affecting around 40 to $60 \%$ of the world's agricultural lands (Shahryari and Mollasadeghi, 2011) where is highly pronounced in arid and semiarid region. Water stress significantly effects on plant growth and crop production and soil properties (Lal et al. 2013). Wheat is the most important cereal crop as staple food grain in Egypt. The statistics indicate that local production of wheat is not enough consumption needs. Water stress rep- resents one of the major limitations to wheat production. Singh et al. (2009) and Mohamed (2013) found that, grain yield and yield components of wheat were decreased with decreasing irrigation water amounts. Moreover, one of the obvious effects of drought on soil is the lack of nutrient uptake by crops, as water is the major medium for moving nutrients into plants as a result of water uptake. The increase in soil temperature associated with lack of soil moisture has an impact on microbial activities 
and nutrient processing, both of which are important for plant use for biomass and grain production. Microbial activities in soil generally are controlled by soil moisture and temperature. The departure from the optimum ranges of soil moisture (water field capacity) and soil temperature (approximately 76-86o F), which varies for different microbial communities in soil, can alter microbial activity. Changes in soil temperature during water stress conditions can affect soil organic matter (SOM) decomposition and increase the release of carbon dioxide. Also, during this process additional mineral $\mathrm{N}$, mostly in the form of nitrate, will be released in the soil system. This change in soil environment affects the stability of SOM and subsequently, affects the soil biological system. Several strategies have been proposed to overcome the effect of water stress on wheat growth and productivity and soil properties. Application of silicon and humic acid were proposed to their role in improving plant growth and yield, enhance stress tolerance as well as to improve soil properties. Silicon is the second most abundant element existing on earth Silva et al. (2012). Although it is not considered as an essential element, nevertheless, there is increasing evidence regarding its positive effects on plant growth and development Karmollachaab et al. (2014). Numerous studies have demonstrated that silicon is one of the important elements of plants, and plays an important role in tolerance of plants to environmental stresses (Savant et al. 1997 and Epstein, 1999). Silicon is also known to increase drought tolerance in plants by maintaining plant water balance, photosynthetic activity, erectness of leaves and structure of xylem vessels under high transpiration rates (Melo et al., 2003; Hattori et al., 2005 and Gong et al., 2003) reported greater water use efficiency by application of Silicon in wheat. Humic acid plays an important role in enhancing wheat production. It increases root vitality, improved nutrient uptake, improve seed germination, increase fertilizer retention, stimulate beneficial microbial activity and improve yield. On the other hand, Humic substances in soil, increase nutrient absorption by augmenting the availability of nutrients in addition to improvement of the physical structure of the soil (Akinremi et al., 2000; Chen et al., 2001; Cimrin and Yilmaz, 2005 and Asal et al., 2015) reported that application of humic acid enhanced root growth and that was directly correlated with enhanced uptake of macro and micronutrients. Therefore, the objective of this work was to detect the effect of water stress on the production of wheat and assessing the role of silicon and humic acid on alleviating the deleterious effect of water stress and improving soil properties.

\section{Materials and Methods}

The present study was carried out at the Experimental Farm of Shandaweel Agricultural Research Station, Agricultural Research Center (ARC), Egypt, during the two successive growing seasons of 2015/2016 and 2016/2017 to study the effect of water stress on yield and its components of wheat and assessing the role of silicon and humic acid on alleviating the deleterious effect of water stress and improving soil physical 
properties. The experiment was laid out in split split plot design with three replications with a plot size of $3 \times 3.5$ $\mathrm{m}$ where, two irrigation regimes $(\mathrm{N}$ : normal irrigation, where the plots were irrigated 5 times throughout the growing season and D: water stress, withholding irrigation after the second irrigation) were allocated in the main plots, four silicon and humic treatments (Control: without application, silicon, humic acid and silicon + humic) were assigned to the sub plots and applied at tillering and booting stage and three wheat cultivars (Shandaweel 1, Sids 12 and Gemmeiza 11) were allocated in the sub sub plots. Planting was done at $25^{\text {th }}$ November in both seasons. All the required agronomic practices were followed uniformly in all plots throughout the growing period. During the tow seasons of study the following data were recorded: days to maturity (DM), plant height (PH, $\mathrm{cm}$.), number of spikes $/ \mathrm{m}^{2}\left(\mathrm{NS} / \mathrm{m}^{2}\right)$, number of kernels/spike (NK/S), 1000-kenel weight (1000-KW, g.), biological yield (BY, ton/fed) and grain yield (GY, ard/fed).

\section{Soil Analysis:}

Soil samples were taken after soil preparation and before fertilization from the experimental site (0-30 $\mathrm{cm}$ depth) for physical and chemical properties. To determine the effect of water stress on soil physical and chemical properties under different experimental conditions, soil samples representing all the treatments were taken after harvest time and soil sample analysis were carried out as described later. The samples were airdried and passed through $2 \mathrm{~mm}$ sieve pores. Particle size was determined by the pipette method (Gee and Orr, 1994) while the organic carbon (OC\%) was analyzed by Walkey and Black procedure (Nelson and Somners, 1982). The $\mathrm{pH}$ was determined in soil/water suspension (1:2.5) according to Jackson (1973). The EC, major cations and anions were measured in the soil peast while $\mathrm{CaCO}_{3}$ was determined using the calcimeter method according to Black (1965). Saturation percentage (SP), field capacity (FC), wilting point (WP) and available water (AW) were determined as described by Hesse (1971).

\section{Statistical analysis:}

All data were analyzed using MSTAT-C computer software package for the differences among treatment means were compared using the least significant differences test (LSD 0.05 ) according to Gomez and Gomez (1984).

\section{Results and Discussions}

\section{Effect of irrigation regimes:}

Results in Table 2 show that the investigated irrigation treatment had significant or highly significant effects on all studied traits in both seasons. The normal irrigation gave the highest significant mean values in all studied traits in both seasons. Water stress reduced days to maturity by (4.67 and 5.27\%), plant height by (6.07 and 6.75\%), number of spikes $/ \mathrm{m}^{2}$ by $(10.87$ and $9.76 \%)$, number of kernels/spike by (11.15 and $14.72 \%), 1000$-kernel weight by (13.34 and 18.27\%), biological yield by (28.47 and $27.14 \%)$ and grain yield by (32.23 and $33.03 \%)$ in the first and second seasons, respectively. Drought-related reduction in yield and yield components of wheat could be to decrease cell growth, leaf area 
and partial stomata closure due to low soil water content, which decreased the intake of $\mathrm{CO}_{2}$ with consequent decrease of photosynthesis per unit area (Acevedo, 1991). Yield reduction is at a maximum when the water stress develops from 10 days before spike emergence. Water stress during this stage also decreases spikelets per spike of fertile tillers (Moustafa et al. 1996). Water stress during grain filling does not affect the number of fertile tillers nor the number of kernels/spike; grain weight is, however, reduced due to a shortening of the grain filling period resulting from accelerated senescence (Kobata et al. 1992). Also, (Saini and Westgate $2000)$ indicated that water deficit initially affected kernel development, which resulting in a decrease in sink potential of kernel and inhibited the enzyme activity directly, thereby causing premature desiccation. Our results are in line with those found by Kang et al. (2002), Abd El-Kreem and El-Hussin (2013) and Said and Abd El-Meneem (2016).

\section{Effect of silicon and humic acid treatments:}

Data presented in Table 2 revealed that silicon and/or humic acid treatments enhanced significantly all studied traits in both seasons as compared to control treatment. The highest mean values of day to maturity (142.56 and 146.44), plant height (107.33 and $109.89 \mathrm{~cm}$ ), number of spikes $/ \mathrm{m}^{2}$ (368.39 and 370.11), number of kernels/spike (49.11 and 53.34), 1000-kernel weight (48.54 and $52.36 \mathrm{~g})$, biological yield (7.87 and $7.50 \mathrm{ton} / \mathrm{fed}$ ) and grain yield (18.65 and $20.41 \mathrm{ard} / \mathrm{fed}$ ) in the first and second seasons, respectively were obtained from plants treated by silicon and humic acid together. While the lowest mean values of (139.11 and 142.89), (103.78 and $104.39 \mathrm{~cm})$, (351.61 and 358.89), (44.79 and 48.11), (44.49 and 47.96 g), (16.24 and $18.25 \mathrm{ard} / \mathrm{fed})$ and (6.73 and 7.20 ton/fed) for the above mentioned traits in the first and second seasons, respectively were recorded with the control treatment. Also, the treatment of silicon or humic acid alone had significantly increased for all studied traits as compared to control treatment. However, there were non-significant differences between these treatments for all studied traits in both seasons except, 1000kernel weight in the second season. These results indicate the role of silicon and humic acid in alleviating the adverse effects of water stress and results in a significant increment of growth, yield and its components. The foliar application of silicon resulted in beneficial effects on chlorophyll fluorescence and photosynthetic pigments, thereby suggesting an enhanced drought tolerance in wheat plants Maghsoudi et al. (2015). Silicon application in wheat depicted marked enhancement in root and shoot weights and decreased transpiration rate of leaves in comparison to plants grown without silicon. It also maintained higher water status, leaf water potential, relative water contents and elevated chlorophyll contents Ali et al. (2013). Silicon application significantly increased plant biomass, plant height and spike weight at all levels of water contents. Poor growth of wheat plants in water deficient conditions was significantly improved with the silicon application 
Ahmed et al. (2007). The highest values of the number of grains/spike, grain weight/spike and 1000-grain weight and grain yield were obtained by foliar spraying with 2 litres of humic acid/feddan Thalooth et al. (2016) and Khan et al. (2010) reported that humic acid applied alone at $3 \mathrm{~kg} / \mathrm{ha}$ the most economical rate to obtain the maximum yield of wheat under rainfed conditions and improve soil fertility. Potassium humate is an effective fertilizer that positively affects growth, yield and chemical constituents of the wheat plant Kandil et al. (2016). Potassium humate increases the rate of nutrient uptake, enhances plant biomass and reduces the soil compaction Canellas et al. (2015).

\section{Effect of wheat cultivars:}

Results in Table 2 show that the three bread wheat cultivars deferred significantly in all studied traits in the two growing seasons. Shandaweell cultivar had the longest maturity duration (143.7 and 147.0 day), while Sids 12 gave the shortest maturity duration (138.08 and 142.54 day) in the first and second seasons, respectively. Data in Table 2 indicate that the highest plant height of 109.88 and $111.83 \mathrm{~cm}$ was recorded in Gemmeiza 11 cultivar, while the shortest plant height of 99.54 and $100.54 \mathrm{~cm}$ was recorded in Sids 12 cultivar in the first and second seasons, respectively. Concerning to the number of spikes $/ \mathrm{m}^{2}$ results show that Shandaweell recorded the highest number of spikes $/ \mathrm{m}^{2}$ (362.29 and 368.46) followed by Gemmeiza 11 (358.33 and 364.58) and Sids 12 (356.83 and $361.21)$ in the first and second seasons, respectively. For the number of kernels/spike data in Table 2 cleared that Shandaweel 1gave the highest number of kernels/spike (37.35 and 51.47), while Gemmeiza 11 gave the lowest number of kernel/spikes (45.38 and 50.18) in the two respective seasons. Regarding to 1000kernel weight, Sids 12 gave the highest mean values of 1000-kernel weight (48.28 and $52.71 \mathrm{~g}$ ), while Shandaweel 1 gave the lowest values of 1000-kernel weight (43.44 and $46.45 \mathrm{~g}$ ) in the two growing seasons, respectively. The results of biological yield (Table 2) show that Gemmeiza 11 gave the highest mean value of biological yield ( 7.40 ton/fed in the first season), while Shandaweel 1 gave the highest mean value ( 7.85 ton/fed in the second season). On the other hand, Sids 12 gave the lowest mean values of biological yield in both seasons. The obtained data of grain yield (ard/fed) in Table 2 indicat that Sids 12 gave the highest mean values of grain yield (18.21 and $20.20 \mathrm{ard} / \mathrm{fed}$ ) followed by Shandaweel 1 (17.47 and $19.44 \mathrm{ard} / \mathrm{fed})$ followed by Gemmeiza 11 (16.72 and $18.13 \mathrm{ard} / \mathrm{fed})$ in the two respective seasons, respectively. The differences between wheat cultivars could be due to their genetic constitutions and their interaction with the environmental factors prevailing during development. Mekkei and El Haggan (2014) concluded that Sids 12 cultivar was more tolerant for water stress compared with other studied cultivars in both seasons. These results are in harmony with those obtained by Abd El-Kreem and El-Hussin (2013), Abdrabo et al. (2016) and Said and Abd El-Meneem (2016). 
4. Effect of interaction between irrigation treatments and silicon and or humic acid treatments:

The interaction between irrigation treatments and silicon and humic acid treatments was significant for number of spikes $/ \mathrm{m}^{2}$ and 1000-kernel weight in both seasons and biological yield in the second season (Table 3 ). Meanwhile, it was insignificant for the other traits under study. The highest mean values of number of spikes $/ \mathrm{m}^{2}$ (387.33 and 387.56) and 1000-kernel weight (51.53 and 57.00 g) were obtained under normal irrigation and silicon+humic acid treatment, whereas the lowest values of number of spikes $/ \mathrm{m}^{2}$ (330.11 and 338.56) and 1000-kernel weight (40.39 and $42.94 \mathrm{~g}$ ) were obtained under water stress and control treatment in the first and second seasons, respectively. Biological yield recorded the highest value (9.42 ton/fed) under normal irrigation and silicon+humic acid treatment, while the lowest value (6.18 ton/fed) was recorded under water stress and control treatment during the second sea-

5. Effect of interaction between irrigation regimes and wheat cultivars:

The illustrated data in Table 4 reveal that the interaction between irrigation treatments and wheat cultivars were significant or highly significant for all studied traits in the two growing seasons except days to maturity in the both seasons, number of spikes $/ \mathrm{m}^{2}$ in the second season, 1000-kernel weight and biological yield in the first season. The highest mean values of plant height (113.42 and $116.00 \mathrm{~cm}$ ) were obtained from Gemmeiza 11 cultivar under normal irrigation, whereas the lowest values $(97.00$ and $97.50 \mathrm{~cm})$ were recorded from Sids 12 cultivar under water stress in the first and second seasons, respectively. Shadaweel 1 cultivar under normal irrigation gave the highest mean value of spikes number $/ \mathrm{m}^{2}$ (383.33), while Gemmeiza 11 gave the lowest value of number of spikes $/ \mathrm{m}^{2}$ (336.00) in the first season. Results in Table 4 showed that Shandaweel 1 had the highest mean values of kernels number/spike (51.18 and 56.57) under normal irrigation first and second season, respectively. In contrast, it had the lowest mean values (43.53 and 46.19) under water stress in the first and second season, respectively. The highest mean value of 1000-kernel weight was recorded from Sids 12 (57.99 g) under normal irrigation, while the lowest mean value was recorded from Shandaweel 1 $(41.20 \mathrm{~g})$ under water stress in the second growing season. Also, the highest grain yield (21.71 and 24.61 ard/fed) were obtained from Sids 12 cultivars under normal irrigation, while le lowest grain yield (13.73 and $15.02 \mathrm{ard} / \mathrm{fed}$ in the first and second seasons, respectively) were recorded from Gemmeiza 11). Furthermore, Sids 12 cultivar subjected to water stress gave the highest grain yield as compared to other cultivars. The highest biological yield was obtained from Shandaweel 1 (9.25 ton/fed), while the lowest biological yield was obtained from Sids 12 cultivar under water stress in the second season. These variations among cultivars might reflect, partially their different genetic backgrounds. Abd El-Kreem and El-Hussin (2013) and Said and Abd El-Meneem (2016) in their stud- 
ies reported that the amount of wheat yield reduction as a result of water stress was affect by genotypes and grain development grain stage.

6. Effect of interaction between silicon and /or humic acid treatments and wheat cultivars:

The interaction between silicon and/or humic acid treatments and wheat cultivars (Table 4) was significant for number of spikes $/ \mathrm{m}^{2}, 1000$ kernel weight and grain yield in the first season and number of kernels/spike in the second season. The highest mean value of spikes number $/ \mathrm{m}^{2}$ (371.50) was obtained from Gemmeiza 11 under silicon+humic acid treatment, while the lowest mean value was recorded from Gemmeiza 11 under control treatment in the first season. Gemmeiza 11 gave the highest mean value of kernels number/spike (53.65) without significant with Shandaweel 1 and Sids 12 under silicon+humic acid treatment, while it gave the lowest mean value of kernels number/spike (46.91) under control treatment in the second growing season. On the other hand, the highest mean value of 1000 -kernel weight $(51.32 \mathrm{~g})$ was recorded from Sids 12 under silicon+humic acid treatment, while the lowest mean value $(42.10$ g) was obtained from Shandaweel 1 with control treatment in the first season. Moreover, Sids 12 gave the highest mean value of grain yield (19.57 ard/fed) under silicon+humic acid treatment, while Gemmeiza 11 gave the lowest mean value of grain yield (15.25 ard/fed) under control treatment in the first season.

7. Effect of second order interaction:
The interaction between silicon and/or humic acid treatments and wheat cultivars was significant for number of kernels/spike in the two growing seasons, biological yield in the first season and 1000-kernel weight in the second season (Table 5 and 6). Results indicated that Shandweel 1 under normal irrigation and silicon+humic acid treatment gave the highest mean values of kernels number/spike (53.53 and 58.00), while it gave the lowest mean values (41.20 and 42.87) under water stress and control treatment in the first and second seasons, respectively. Moreover, Sids 12 had the highest mean value $(60.0 \mathrm{~g})$ of 1000 -kernel weight under normal irrigation and silicon+humic acid treatment, while Shandaweel 1 had the lowest mean value (39.36 g) under water stress and control treatment in the second season. On the other hand, Gemmeiza 11 cultivar gave the highest mean value of biological yield (9.21 ton/fed) under normal irrigation and silicon+humic acid treatment, while it gave the lowest mean value $(5.32$ ton/fed) under water stress and control treatment in the first season.

\section{Soil chemical and physical properties}

In order to investigate the effect of water stress and "humic acid and silicon" applications on soil properties, some soil properties were determined. The soil texture was silt loam of the soil under investigation wherein the ratio of clay was $(20.96 \%)$; silt $(56 \%)$; sand $(23.04 \%)$. Soil texture didn't change during the experiment under normal and water stress condition while many of soil properties had 
been significant and insignificant affected under water stress condition.

\subsection{Effect of irrigation treat- ment on soil properties:}

The obtained data, which represented in tables 7 and 8 show no change occurred on soil chemical and physical properties approximately under normal irrigation. However, water stress caused a slight change in physical properties occurred. Water stress caused insignificant slightly decrease in field capacity (FC), wilting point (WP), available water (AW), saturation percentage (SP), and porosity due to significant change in organic carbon (OC) content during two seasons than normal irrigation Geng et al. (2014). Furthermore, Calcium carbonate value was $3.7 \%$ and $3.8 \%$ in the soil before planting through first and second seasons respectively. Water stress caused increasing in $\mathrm{CaCO}_{3}$ percent to 3.8 and to $3.9 \%$ through first and second seasons respectively.

The effect of irrigation treatment on chemical properties of soil was illustrated in Table 8 . The results show that water stress caused an increase in EC, major cations and major anions values with significant effect, and with insignificant effect on $\mathrm{pH}$ values according to $f$ test value, while normal irrigation has insignificant effect on soil chemical properties. The EC was increased due to the reduction soil moisture. Over and above the effect of water stress on soil properties was in good agreement with the three bread wheat cultivars yield results where waters tress caused reduced in the three wheat cultivars yield as described before and soil deterioration in soil properties.

\subsection{Effect of silicon and humic acid treatments on soil properties:}

The obtained data which represented in tables 7 and 8 show the silicon foliar application hadn't affected on chemical and physical properties under normal and water stress conditions. This refers to only less than $20 \%$ of silicon concentration reach to the soil. On the other hand, the application of humate significantly affected soil chemical and some physical properties. The results explained that humate application significantly affect and increase (OC), and (SP) while caused insignificant increasing in (FC), (WP) and Porosity percentage values (Ibrahim and Goh 2004). Humic acid can play a very important role in soil conditioning due to increase the water holding capacity of the soil and forming of organomineral complexes by functional groups of the humic acids (Glaser et al. 2002). Moreover, humic acid has the very unique ability to increase water retention in soils where, the negative charge of humic acids attracts positive ions, or cations, which stick to the humic molecule. These cations, in the presence of water molecules, move slightly away from the humic molecule and attach loosely to the oxygen end of water molecules. The hydrogen ends of those water molecules then attach to the hydrogen ends of other water molecules. This effect reduces water evaporation by up to $30 \%$ (Cihláŕ et al. 2014). Furthermore, humic acid is able to bond to all soil particles, which creates necessary space for microbes and healthy root growth. This is especially noticeable in high-clay and compacted soils, where soil particles 
are bound tightly together. Humic molecules are even capable of standing clay particles at the end, which allows more space and water penetration. Further, they remove salts from clay, which restores a negative charge from the clay particles, forcing them apart (Magdoff and VAN Es 2009). Consequently, humic acid reduced water stress effect on soil physical properties. Whereas, humate application reduced water stress effect on soil chemical properties through increase the resistance to the increasing in EC values, where humic acid acts as a chelating agent to metal ions (Kumar et al. 2013). However, adding humic acid in humate salt form caused increasing on $\mathrm{pH}$ value, whereas at the end of two season $\mathrm{pH}$ values return to normal level according soil buffer effect. Thus, humic acid application reduced soil deterioration which caused by long term effect of water stress.

However, humic acid played very important role in enhancing and resisting water stress effect on soil properties while the treatment factor by using "humic acid + silicon" application has more pronouncing effect on three wheat cultivars to challenging water stress effect.

\section{Conclusion}

In this study, the influence of water stress on three wheat cultivars and some soil properties was evaluated. The results explained that water stress had a significant or highly significant effect on the three wheat cultivars in studying traits in both seasons where water stress reduced all plant growth properties. Moreover, water stress had significant on chemical properties of soil while had an insignificant effect on physical properties except OC content was significantly affected by water stress.

Silicon and humic acid application had been applied as foliar and soil addition respectively to resisting the water stress effect. The results explain that treatment of silicon or humic acid effected significantly in all the studied traits in both seasons as compared to control treatment under water stress conditions. Whereas, humic acid played a very important role and had a significant effect of resisting the effect of water stress on soil chemical and physical properties while silicon hadn't affected or played any role on soil properties. 
Table 1. Mean of studied traits of wheat cultivars as affected by irrigation treatments, silicon and humic acid treatments in 2015/2016 and 2016/2017 seasons.

\begin{tabular}{|c|c|c|c|c|c|c|c|c|}
\hline $\begin{array}{l}0 \\
\mathbb{J} \\
\tilde{W}\end{array}$ & Treatments & $\begin{array}{c}\text { Days to } \\
\text { maturity }\end{array}$ & $\begin{array}{l}\text { Plant } \\
\text { height } \\
(\mathrm{cm}) .\end{array}$ & $\begin{array}{c}\text { No. of } \\
\text { spikes/ } \\
\mathrm{m}^{2} \\
\end{array}$ & $\begin{array}{l}\text { No. of } \\
\text { kernels/ } \\
\text { spike }\end{array}$ & $\begin{array}{l}1000- \\
\text { kernel } \\
\text { weight }\end{array}$ & $\begin{array}{c}\text { Grain } \\
\text { yield } \\
\text { (ard } / \text { fed) }\end{array}$ & $\begin{array}{c}\text { Biological } \\
\text { yield } \\
\text { (ton/fed) }\end{array}$ \\
\hline \multicolumn{9}{|c|}{ Environments } \\
\hline \multirow{4}{*}{ i) } & Normal & 144.58 & 108.83 & 379.92 & 49.42 & 49.86 & 20.82 & 8.43 \\
\hline & Water stress & 137.83 & 102.22 & 338.61 & 43.91 & 43.21 & 14.11 & 6.03 \\
\hline & Reduction\% & 4.67 & 6.07 & 10.87 & 11.15 & 13.34 & 32.23 & 28.47 \\
\hline & F test & $* *$ & $* *$ & $* *$ & $*$ & $*$ & $* *$ & $* *$ \\
\hline \multirow{4}{*}{ 공 } & Normal & 148.64 & 111.11 & 383.47 & 54.75 & 55.12 & 23.07 & 8.77 \\
\hline & Water stress & 140.81 & 103.61 & 346.03 & 46.69 & 45.05 & 15.45 & 6.39 \\
\hline & Reduction\% & -5.27 & -6.75 & -9.76 & -14.72 & -18.27 & -33.03 & -27.14 \\
\hline & F test & $* *$ & $* *$ & $* *$ & $* *$ & $* *$ & $* *$ & $* *$ \\
\hline \multicolumn{9}{|c|}{ Treatments } \\
\hline & Control & 139.11 & 103.78 & 351.61 & 44.79 & 44.49 & 16.24 & 6.73 \\
\hline & Silicon & 141.39 & 105.22 & 359.67 & 46.42 & 46.40 & 17.69 & 7.20 \\
\hline & Humic & 141.78 & 105.78 & 357.94 & 46.34 & 46.71 & 17.28 & 7.13 \\
\hline & Silicon+Humic & 142.56 & 107.33 & 368.39 & 49.11 & 48.54 & 18.65 & 7.87 \\
\hline \multicolumn{2}{|c|}{ F test } & $* *$ & $* *$ & $* *$ & $* *$ & $* *$ & $* *$ & $* *$ \\
\hline \multicolumn{2}{|c|}{ L.S.D 0.05 } & 1.40 & 1.58 & 3.27 & 1.34 & 0.79 & 0.89 & 0.44 \\
\hline & Control & 142.89 & 104.39 & 358.89 & 48.11 & 47.96 & 18.25 & 7.20 \\
\hline & Silicon & 144.44 & 107.39 & 363.33 & 50.26 & 50.50 & 19.07 & 7.59 \\
\hline & Humic & 145.11 & 107.78 & 366.67 & 51.16 & 49.54 & 19.30 & 7.50 \\
\hline & Silicon+Humic & 146.44 & 109.89 & 370.11 & 53.34 & 52.36 & 20.41 & 8.02 \\
\hline \multicolumn{2}{|c|}{ F test } & $* *$ & $* *$ & $* *$ & $* *$ & $* *$ & $* *$ & $* *$ \\
\hline \multicolumn{2}{|c|}{ L.S.D 0.05} & 0.86 & 1.52 & 3.38 & 1.24 & 0.43 & 0.78 & 0.28 \\
\hline \multicolumn{9}{|c|}{ Cultivars } \\
\hline & Shandaweel 1 & 143.71 & 107.17 & 362.29 & 47.35 & 43.44 & 17.47 & 7.21 \\
\hline & Sids 12 & 138.08 & 99.54 & 356.83 & 47.26 & 48.28 & 18.21 & 7.09 \\
\hline & Gemmeiza 11 & 141.83 & 109.88 & 358.33 & 45.38 & 47.89 & 16.72 & 7.40 \\
\hline \multicolumn{2}{|c|}{ F test } & $* *$ & $* *$ & $* *$ & $* *$ & $* *$ & $* *$ & * \\
\hline \multicolumn{2}{|c|}{ L.S.D 0.05} & 1.38 & 0.95 & 2.87 & 0.97 & 0.94 & 0.50 & 0.21 \\
\hline \multirow{3}{*}{ 궁 } & Shandaweel 1 & 147.04 & 109.71 & 368.46 & 51.47 & 46.45 & 19.44 & 7.85 \\
\hline & Sids 12 & 142.54 & 100.54 & 361.21 & 50.52 & 52.71 & 20.20 & 7.42 \\
\hline & Gemmeiza 11 & 144.58 & 111.83 & 364.58 & 50.18 & 51.10 & 18.13 & 7.46 \\
\hline \multicolumn{2}{|c|}{ F test } & $* *$ & ** & $* *$ & * & ** & $* *$ & $* *$ \\
\hline \multicolumn{2}{|c|}{ L.S.D 0.05} & 1.23 & 0.84 & 3.06 & 0.85 & 0.61 & 0.59 & 0.24 \\
\hline
\end{tabular}

Where $*$ and $* *$ mean significant at 0.05 and 0.01 levels of probability, respectively. 
Website: www.aun.edu.eg/faculty_agriculture/journals_issues_form.php E-mail:ajas@aun.edu.eg

Table 2. Effect of the interaction between irrigation treatments and each of silicon and humic treatments and the three wheat cultivars for the studied traits in 2015/2016 and 2016/2017 seasons.

\begin{tabular}{|c|c|c|c|c|c|c|c|c|c|}
\hline 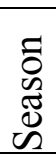 & $\mathrm{T} 1$ & ents & \begin{tabular}{|c} 
Days \\
to matur- \\
ity
\end{tabular} & $\begin{array}{c}\text { Plant } \\
\text { height, } \\
\mathrm{cm} . \\
\end{array}$ & $\begin{array}{c}\text { No. of } \\
\text { spikes/ } \\
\mathrm{m}^{2} \\
\end{array}$ & $\begin{array}{c}\text { No. of } \\
\text { kernels/ } \\
\text { spike }\end{array}$ & $\begin{array}{l}1000- \\
\text { kernel } \\
\text { weight }\end{array}$ & $\begin{array}{c}\text { Grain } \\
\text { yield } \\
\text { (ard/fed) }\end{array}$ & $\begin{array}{c}\text { Biological } \\
\text { yield } \\
\text { (ton } / \text { fed) }\end{array}$ \\
\hline \multicolumn{10}{|c|}{ Interaction between irrigation and silicon and humic acid } \\
\hline \multirow{8}{*}{ O) } & \multirow{4}{*}{$\mathrm{N}$} & Control & 142.00 & 107.33 & 373.11 & 47.75 & 48.60 & 19.64 & 7.88 \\
\hline & & Silicon & 145.11 & 108.44 & 383.00 & 49.33 & 49.64 & 21.40 & 8.62 \\
\hline & & Humic & 145.33 & 109.11 & 375.33 & 48.86 & 49.67 & 20.15 & 8.20 \\
\hline & & Silicon+Humic & 145.89 & 110.44 & 387.33 & 51.74 & 51.53 & 22.09 & 9.03 \\
\hline & \multirow{4}{*}{$\mathrm{D}$} & Control & 136.22 & 100.22 & 330.11 & 41.83 & 40.39 & 12.85 & 5.59 \\
\hline & & Silicon & 137.67 & 102.00 & 336.33 & 43.51 & 43.15 & 13.98 & 5.78 \\
\hline & & Humic & 138.22 & 102.44 & 338.56 & 43.82 & 43.74 & 14.41 & 6.05 \\
\hline & & Silicon+Humic & 139.22 & 104.22 & 349.44 & 46.47 & 45.54 & 15.21 & 6.70 \\
\hline \multicolumn{3}{|c|}{ F test } & Ns & Ns & $*$ & Ns & $*$ & Ns & Ns \\
\hline \multicolumn{3}{|c|}{ L.S.D 0.05} & - & - & 4.63 & - & 1.12 & - & - \\
\hline \multirow{8}{*}{$\frac{\bar{\sigma}}{8}$} & \multirow{4}{*}{$\mathrm{N}$} & Control & 147.11 & 108.11 & 379.22 & 51.44 & 52.98 & 22.31 & 8.11 \\
\hline & & Silicon & 148.44 & 111.67 & 382.89 & 54.11 & 55.96 & 22.86 & 8.72 \\
\hline & & Humic & 149.11 & 111.00 & 384.22 & 56.11 & 54.56 & 23.04 & 8.82 \\
\hline & & Silicon+Humic & 149.89 & 113.67 & 387.56 & 57.33 & 57.00 & 24.05 & 9.42 \\
\hline & \multirow{4}{*}{ D } & Control & 138.67 & 100.67 & 338.56 & 44.78 & 42.94 & 14.19 & 6.28 \\
\hline & & Silicon & 140.44 & 103.11 & 343.78 & 46.42 & 45.03 & 15.28 & 6.46 \\
\hline & & Humic & 141.11 & 104.56 & 349.11 & 46.21 & 44.53 & 15.57 & 6.18 \\
\hline & & Silicon+Humic & 143.00 & 106.11 & 352.67 & 49.35 & 47.72 & 16.76 & 6.63 \\
\hline \multicolumn{3}{|c|}{ F test } & Ns & Ns & $*$ & Ns & $*$ & Ns & $*$ \\
\hline \multicolumn{3}{|c|}{ L.S.D 0.05} & - & - & 3.37 & - & 0.61 & - & 0.40 \\
\hline \multicolumn{10}{|c|}{ Interaction between irrigation and wheat cultivars } \\
\hline \multirow{6}{*}{ 足 } & \multirow{3}{*}{$\mathrm{Z}$} & Shandaweel 1 & 146.92 & 111.00 & 383.33 & 51.18 & 46.73 & 21.04 & 8.42 \\
\hline & & Sids 12 & 141.83 & 102.08 & 375.08 & 50.11 & 51.43 & 21.71 & 8.23 \\
\hline & & Gemmeiza 11 & 145.00 & 113.42 & 380.67 & 46.98 & 51.43 & 19.71 & 8.64 \\
\hline & \multirow{3}{*}{$\mathrm{D}$} & Shandaweel 1 & 140.50 & 103.33 & 341.25 & 43.53 & 40.15 & 13.89 & 5.99 \\
\hline & & Sids 12 & 134.33 & 97.00 & 338.58 & 44.41 & 45.13 & 14.72 & 5.94 \\
\hline & & Gemme & 138.67 & 106.33 & 336.00 & 43.78 & 44.34 & 13.73 & 6.16 \\
\hline \multicolumn{3}{|c|}{ F test } & Ns & * & * & $* *$ & $\mathrm{Ns}$ & $* *$ & Ns \\
\hline \multicolumn{3}{|c|}{ L.S.D 0.05} & - & 1.34 & 4.06 & 1.37 & - & 0.70 & - \\
\hline \multirow{6}{*}{ 궁 } & \multirow{3}{*}{$\mathrm{N}$} & Shandaweel 1 & 151.17 & 113.75 & 387.83 & 56.75 & 51.71 & 23.34 & 9.25 \\
\hline & & Sids 12 & 146.17 & 103.58 & 378.33 & 54.75 & 57.99 & 24.61 & 8.56 \\
\hline & & Gemmeiza 11 & 148.58 & 116.00 & 384.25 & 52.75 & 55.67 & 21.24 & 8.49 \\
\hline & \multirow{3}{*}{$\mathrm{D}$} & Shandaweel 1 & 142.92 & 105.67 & 349.08 & 46.19 & 41.20 & 15.54 & 6.45 \\
\hline & & Sids 12 & 138.92 & 97.50 & 344.08 & 46.28 & 47.43 & 15.79 & 6.29 \\
\hline & & Gemme & 140.58 & 107.67 & 344.92 & 47.60 & 46.53 & 15.02 & 6.42 \\
\hline \multicolumn{3}{|c|}{ F test } & Ns & * & Ns & $* *$ & * & $* *$ & $*$ \\
\hline \multicolumn{3}{|c|}{ L.S.D 0.05} & - & 1.19 & - & 1.20 & 0.86 & 0.83 & 0.35 \\
\hline
\end{tabular}

\section{$\mathrm{N}=$ normal irrigation $\quad \mathrm{D}=$ water stress}

Where Ns, * and ** means non-significant, significant at 0.05 and 0.01 levels of probability, respectively. 
Table 3. Effect of the interaction between of silicon and humic treatments and the three wheat cultivars for the studied traits in 2015/2016 and 2016/2017 seasons.

\begin{tabular}{|c|c|c|c|c|c|c|c|c|c|}
\hline $\begin{array}{l}\tilde{0} \\
\tilde{\Xi} \\
\tilde{\Xi} \\
\tilde{\omega}\end{array}$ & Trea & nents & \begin{tabular}{|c} 
Days \\
to matur- \\
ity
\end{tabular} & $\begin{array}{c}\text { Plant } \\
\text { height, } \\
\mathrm{cm} .\end{array}$ & $\begin{array}{c}\text { No. of } \\
\text { spikes/ } \\
\mathrm{m}^{2}\end{array}$ & $\begin{array}{c}\text { No. of } \\
\text { kernels/ } \\
\text { spike }\end{array}$ & $\begin{array}{l}1000- \\
\text { kernel } \\
\text { weight }\end{array}$ & $\begin{array}{c}\text { Grain } \\
\text { yield } \\
\text { (ard } / \text { fed })\end{array}$ & $\begin{array}{c}\text { Biological } \\
\text { yield } \\
\text { (ton/fed) }\end{array}$ \\
\hline \multirow{12}{*}{$\begin{array}{l}0 \\
\stackrel{1}{\sim} \\
\end{array}$} & \multirow{3}{*}{\begin{tabular}{l}
$\overline{0}$ \\
\multirow{2}{0}{} \\
वे
\end{tabular}} & Shandaweel 1 & 141.33 & 104.67 & 358.33 & 45.68 & 42.10 & 16.77 & 7.07 \\
\hline & & Sids 12 & 136.67 & 98.33 & 349.17 & 45.25 & 46.91 & 16.71 & 6.44 \\
\hline & & Gemmeiza 11 & 139.33 & 108.33 & 347.33 & 43.44 & 44.47 & 15.25 & 6.68 \\
\hline & \multirow{3}{*}{$\frac{\overline{0}}{\bar{n}}$} & Shandaweel 1 & 144.00 & 107.17 & 361.67 & 47.22 & 43.22 & 17.12 & 6.95 \\
\hline & & Sids 12 & 138.33 & 99.33 & 358.33 & 47.30 & 46.83 & 18.73 & 7.06 \\
\hline & & Gemmeiza 11 & 141.83 & 109.17 & 359.00 & 44.75 & 49.14 & 17.23 & 7.59 \\
\hline & & Shandaweel 1 & 144.33 & 108.00 & 361.67 & 47.25 & 43.85 & 17.85 & 7.05 \\
\hline & & Sids 12 & 138.17 & 99.50 & 353.67 & 46.45 & 48.05 & 17.84 & 6.96 \\
\hline & & Gemmeiza 11 & 142.83 & 109.83 & 355.50 & 45.32 & 48.22 & 16.14 & 7.37 \\
\hline & \multirow{3}{*}{ 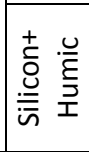 } & Shandaweel 1 & 145.17 & 108.83 & 367.50 & 49.27 & 44.58 & 18.13 & 7.76 \\
\hline & & Sids 12 & 139.17 & 101.00 & 366.17 & 50.05 & 51.32 & 19.57 & 7.89 \\
\hline & & Gemmeiza 11 & 143.33 & 112.17 & 371.50 & 48.00 & 49.71 & 18.26 & 7.95 \\
\hline \multicolumn{3}{|c|}{ F test } & Ns & Ns & $*$ & $\mathrm{Ns}$ & * & $*$ & Ns \\
\hline \multicolumn{3}{|c|}{ L.S.D 0.05} & - & - & 5.74 & - & 1.88 & 0.99 & - \\
\hline \multirow{12}{*}{ 穴 } & \multirow{3}{*}{ 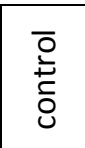 } & Shandaweel 1 & 145.50 & 106.67 & 365.00 & 48.94 & 44.10 & 18.26 & 7.67 \\
\hline & & Sids 12 & 140.67 & 97.83 & 354.17 & 48.49 & 50.54 & 19.48 & 7.09 \\
\hline & & Gemmeiza 11 & 142.50 & 108.67 & 357.50 & 46.91 & 49.23 & 17.02 & 6.83 \\
\hline & \multirow{3}{*}{ 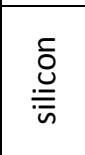 } & Shandaweel 1 & 146.83 & 109.83 & 366.83 & 52.90 & 47.02 & 19.45 & 7.79 \\
\hline & & Sids 12 & 142.50 & 100.17 & 361.00 & 48.92 & 52.36 & 19.85 & 7.40 \\
\hline & & Gemmeiza 11 & 144.00 & 112.17 & 362.17 & 48.98 & 52.12 & 17.91 & 7.58 \\
\hline & \multirow{3}{*}{ 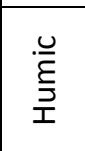 } & Shandaweel 1 & 147.17 & 110.33 & 369.67 & 50.50 & 46.09 & 19.22 & 7.67 \\
\hline & & Sids 12 & 142.67 & 100.83 & 363.50 & 51.82 & 52.69 & 20.24 & 7.58 \\
\hline & & Gemmeiza 11 & 145.50 & 112.17 & 366.83 & 51.17 & 49.84 & 18.45 & 7.25 \\
\hline & \multirow{3}{*}{ 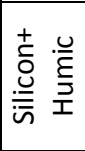 } & Shandaweel 1 & 148.67 & 112.00 & 372.33 & 53.54 & 48.61 & 20.84 & 8.27 \\
\hline & & Sids 12 & 144.33 & 103.33 & 366.17 & 52.84 & 55.25 & 21.22 & 7.63 \\
\hline & & Gemmeiza 11 & 146.33 & 114.33 & 371.83 & 53.65 & 53.23 & 19.16 & 8.17 \\
\hline \multicolumn{3}{|c|}{ F test } & $\mathrm{Ns}$ & Ns & $\mathrm{Ns}$ & $* *$ & $\mathrm{Ns}$ & Ns & $\mathrm{Ns}$ \\
\hline \multicolumn{3}{|c|}{ L.S.D 0.05} & - & - & - & 1.70 & - & - & - \\
\hline
\end{tabular}

Where Ns, * and ** means non-significant, significant at 0.05 and 0.01 levels of probability, respectively. 
Website: www.aun.edu.eg/faculty_agriculture/journals_issues_form.php E-mail: ajas@aun.edu.eg

Table 4. Effect of the interaction between irrigation regimes, Silicon and Humic acid treatments and the three wheat cultivars for the studied traits in 2015/2016 season.

\begin{tabular}{|c|c|c|c|c|c|c|c|c|c|}
\hline \multicolumn{3}{|c|}{$\mathrm{T}_{\text {Treatments }}^{\text {Traits }}$} & $\begin{array}{l}\text { Days } \\
\text { to ma- } \\
\text { turity }\end{array}$ & $\begin{array}{l}\text { Plant } \\
\text { height, } \\
\text { cm. }\end{array}$ & \begin{tabular}{|c|}
$\begin{array}{c}\text { No. of } \\
\text { spikes/ } \\
\mathbf{m}^{2}\end{array}$ \\
\end{tabular} & $\begin{array}{c}\text { No. of } \\
\text { kernels/ } \\
\text { spike } \\
\end{array}$ & $\begin{array}{l}1000- \\
\text { kernel } \\
\text { weight } \\
\end{array}$ & $\begin{array}{c}\text { Grain } \\
\text { yield } \\
\text { (ard/fed) }\end{array}$ & \begin{tabular}{|c|} 
Biological \\
yield \\
(ton $/$ fed $)$ \\
\end{tabular} \\
\hline \multirow{12}{*}{ 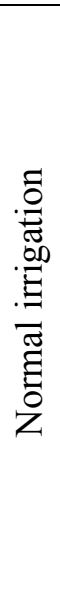 } & \multirow{3}{*}{ 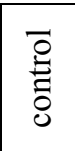 } & Shandaweel 1 & 144.33 & 109.00 & 380.33 & 50.17 & 46.90 & 20.77 & 8.07 \\
\hline & & Sids 12 & 139.67 & 100.67 & 368.33 & 48.50 & 50.47 & 20.28 & 7.52 \\
\hline & & Gemmeiza 11 & 142.00 & 112.33 & 370.67 & 44.58 & 48.43 & 17.87 & 8.04 \\
\hline & \multirow{3}{*}{ 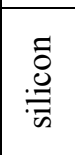 } & Shandaweel 1 & 147.67 & 110.67 & 385.00 & 50.00 & 45.93 & 20.87 & 8.19 \\
\hline & & Sids 12 & 142.00 & 102.00 & 376.00 & 52.00 & 50.47 & 22.33 & 60 \\
\hline & & Gemmeiza 11 & 145.67 & 112.67 & 388.00 & 46.00 & 52.53 & 21.00 & 9.07 \\
\hline & \multirow{3}{*}{ 总 } & Shandaweel 1 & 147.67 & 112.00 & 382.00 & 51.00 & 46.40 & .13 & 45 \\
\hline & & Sids 12 & 142.33 & 102.33 & 372.00 & 47.58 & 50.48 & 20.91 & 7.92 \\
\hline & & Gemmeiza 11 & 146.00 & 113.00 & 372.00 & 48.00 & 52.14 & 18.40 & 8.24 \\
\hline & \multirow{3}{*}{ 㕝 } & Shandaweel 1 & 148.00 & 112.33 & 386.00 & 53.53 & 47.67 & 21.40 & .99 \\
\hline & & Sids 12 & 143.33 & 103.33 & 384.00 & 52.37 & 54.30 & 23.30 & 8.89 \\
\hline & & Gemmeiza 11 & 146.33 & 115.67 & 392.00 & 49.33 & 52.62 & 21.58 & 21 \\
\hline \multirow{12}{*}{ 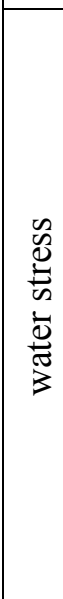 } & \multirow{3}{*}{$\begin{array}{l}\overline{0} \\
\stackrel{0}{0}\end{array}$} & Shandaweel 1 & 138.33 & 100.33 & 336.33 & 41.20 & 37.30 & 12.77 & 6.08 \\
\hline & & Sids 12 & 133.67 & 96.00 & 330.00 & 42.00 & 43.36 & 13.13 & 5.36 \\
\hline & & Gemmeiza 11 & 136.67 & 104.33 & 324.00 & 42.30 & 40.50 & 12.64 & 5.32 \\
\hline & \multirow{3}{*}{ :0 } & Shandaweel 1 & 140.33 & 103.67 & 338.33 & 44.43 & 40.50 & 13.37 & 5.72 \\
\hline & & Sids 12 & 134.67 & 96.67 & 340.67 & 42.60 & 43.20 & 15.13 & 5.51 \\
\hline & & Gemmeiza 11 & 138.00 & 105.67 & 330.00 & 43.50 & 45.75 & 13.45 & 6.11 \\
\hline & \multirow[t]{3}{*}{ 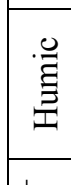 } & Shandaweel 1 & 141.00 & 104.00 & 341.33 & 43.50 & 41.30 & 14.57 & 5.64 \\
\hline & & Sids 12 & 134.00 & 96.67 & 335.33 & 45.32 & 45.62 & 14.77 & 6.00 \\
\hline & & Gemmeiza 11 & 139.67 & 106.67 & 339.00 & 42.63 & 44.30 & 13.88 & 6.51 \\
\hline & \multirow{3}{*}{ 总 } & Shandaweel 1 & 142.33 & 105.33 & 349.00 & 45.00 & 41.50 & 14.87 & 6.53 \\
\hline & & Sids 12 & 135.00 & 98.67 & 348.33 & 47.73 & 48.33 & 15.83 & 6.89 \\
\hline & & Gemmeiza 11 & 140.33 & 108.67 & 351.00 & 46.67 & 46.80 & 14.93 & 6.68 \\
\hline \multicolumn{3}{|c|}{ F test } & $\overline{\mathrm{Ns}}$ & $\mathrm{Ns}$ & $\mathrm{Ns}$ & & $\mathrm{Ns}$ & $\overline{\mathrm{Ns}}$ & * \\
\hline \multicolumn{3}{|c|}{ L.S.D 0.05} & - & - & - & 2.73 & - & - & 0.60 \\
\hline
\end{tabular}

Where Ns, ${ }^{*}$ and $* *$ means non-significant, significant at 0.05 and 0.01 levels of probability, respectively. 
Table 5. Effect of the interaction between irrigation regimes, Silicon and Humic treatments and the three wheat cultivars for the studied traits in $2016 / 2017$ season.

\begin{tabular}{|c|c|c|c|c|c|c|c|c|c|}
\hline \multicolumn{3}{|c|}{ Treatments } & $\begin{array}{c}\text { Days } \\
\text { to matur- } \\
\text { ity }\end{array}$ & $\begin{array}{c}\text { Plant } \\
\text { height, } \\
\mathrm{cm} .\end{array}$ & $\begin{array}{c}\text { No. of } \\
\text { spikes/ } \\
\mathrm{m}^{2} \\
\end{array}$ & $\begin{array}{c}\text { No. of } \\
\text { kernels/ } \\
\text { spike } \\
\end{array}$ & $\begin{array}{l}1000- \\
\text { kernel } \\
\text { weight }\end{array}$ & $\begin{array}{c}\text { Grain } \\
\text { yield } \\
(\text { ard } / \text { fed })\end{array}$ & $\begin{array}{c}\text { Biological } \\
\text { yield } \\
\text { (ton/fed) }\end{array}$ \\
\hline \multirow{12}{*}{ 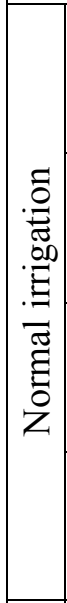 } & \multirow{3}{*}{ 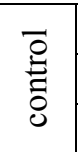 } & Shandaweel 1 & 149.67 & 110.67 & 386.33 & 55.00 & 48.83 & 22.87 & 8.57 \\
\hline & & Sids 12 & 145.00 & 101.00 & 372.00 & 51.67 & 55.63 & 23.96 & 7.85 \\
\hline & & Gemmeiza 11 & 146.67 & 112.67 & 379.33 & 47.67 & 54.47 & 20.10 & 7.91 \\
\hline & \multirow{3}{*}{ 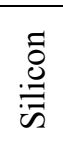 } & Shandaweel 1 & 151.00 & 114.67 & 386.67 & 57.67 & 52.67 & 23.24 & 9.22 \\
\hline & & Sids 12 & 146.33 & 103.33 & 378.67 & 53.00 & 58.66 & 24.34 & 8.60 \\
\hline & & Gemmeiza 11 & 148.00 & 117.00 & 383.33 & 51.67 & 56.56 & 21.00 & 8.33 \\
\hline & \multirow{3}{*}{ 兽 } & Shandaweel 1 & 151.33 & 113.67 & 389.00 & 56.33 & 52.00 & 98 & 9.20 \\
\hline & & Sids 12 & 146.33 & 103.67 & 379.67 & 56.67 & 57.67 & 24.80 & 8.87 \\
\hline & & Gemmeiza 11 & 149.67 & 115.67 & 384.00 & 55.33 & 54.00 & 21.34 & 8.40 \\
\hline & \multirow{3}{*}{ 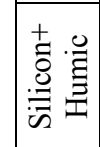 } & Shandaweel 1 & 152.67 & 116.00 & 389.33 & 58.00 & 53.33 & 24.27 & 10.00 \\
\hline & & Sids 12 & 147.00 & 106.33 & 383.00 & 57.67 & 60.00 & 25.35 & 8.93 \\
\hline & & Gemmeiza 11 & 150.00 & 118.67 & 390.33 & 56.33 & 57.67 & 22.53 & 9.33 \\
\hline \multirow{12}{*}{ 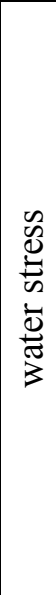 } & \multirow{3}{*}{$\begin{array}{l}\overline{0} \\
\text { : } \\
\text { 잉 }\end{array}$} & Shandaweel 1 & 141.33 & 102.67 & 343.67 & 42.87 & 39.36 & 13.64 & 6.76 \\
\hline & & Sids 12 & 136.33 & 94.67 & 336.33 & 45.31 & 45.45 & 15.00 & 6.32 \\
\hline & & Gemmeiza 11 & 138.33 & 104.67 & 335.67 & 46.15 & 44.00 & 13.93 & 5.76 \\
\hline & \multirow{3}{*}{9} & Shandaweel 1 & 142.67 & 105.00 & 347.00 & 48.13 & 41.37 & 15.66 & 6.36 \\
\hline & & Sids 12 & 138.67 & 97.00 & 343.33 & 44.83 & 46.07 & 15.37 & 6.20 \\
\hline & & Gemmeiza 11 & 140.00 & 107.33 & 341.00 & 46.28 & 47.67 & 14.81 & 6.82 \\
\hline & \multirow{3}{*}{ 总 } & Shandaweel 1 & 143.00 & 107.00 & 350.33 & 44.67 & 40.19 & 15.47 & 6.14 \\
\hline & & Sids 12 & 139.00 & 98.00 & 347.33 & 46.97 & 47.71 & 15.68 & 6.29 \\
\hline & & Gemmeiza 11 & 141.33 & 108.67 & 349.67 & 47.00 & 45.68 & 15.56 & 6.11 \\
\hline & \multirow{3}{*}{ 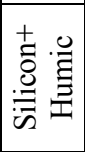 } & Shandaweel 1 & 144.67 & 108.00 & 355.33 & 49.09 & 43.88 & 17.41 & 6.55 \\
\hline & & Sids 12 & 141.67 & 100.33 & 349.33 & 48.00 & 50.49 & 17.10 & 6.33 \\
\hline & & Gemmeiza 11 & 142.67 & 110.00 & 353.33 & 50.96 & 48.79 & 15.78 & 7.00 \\
\hline \multicolumn{3}{|c|}{ F test } & Ns & Ns & Ns & $*$ & 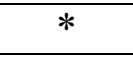 & Ns & Ns \\
\hline \multicolumn{3}{|c|}{ L.S.D 0.05 } & - & - & - & 2.40 & 1.73 & - & - \\
\hline
\end{tabular}

Where Ns, $*$ and $* *$ means non-significant, significant at 0.05 and 0.01 levels of probability, respectively. 
Website: www.aun.edu.eg/faculty_agriculture/journals_issues_form.php E-mail: ajas@aun.edu.eg

Table 6. Physical analysis of soil samples under investigation.

\begin{tabular}{|c|c|c|c|c|c|c|c|c|c|}
\hline 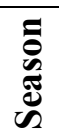 & \multicolumn{2}{|c|}{ Treatments } & $\begin{array}{c}\mathrm{SP} \\
\mathrm{mL} / 100 \mathrm{~g}\end{array}$ & OC\% & FC\% & WP\% & AW\% & Porosity\% & $\mathrm{CaCO}_{3} \%$ \\
\hline \multirow{9}{*}{$\stackrel{0}{\circ}$} & \multicolumn{2}{|c|}{ Before planting } & 41 & 0.38 & 29.2 & 12.6 & 16.6 & 48.4 & 3.70 \\
\hline & \multirow{4}{*}{$\mathrm{N}$} & Control & 42 & 0.37 & 29.2 & 12.6 & 16.6 & 48.4 & 3.72 \\
\hline & & Silicon & 41 & 0.37 & 29.2 & 12.6 & 16.6 & 48.4 & 3.72 \\
\hline & & Humic & 45 & 0.47 & 29.8 & 12.7 & 16.9 & 48.5 & 3.70 \\
\hline & & Silicon+Humic & 45 & 0.46 & 29.7 & 12.8 & 16.8 & 48.5 & 3.70 \\
\hline & \multirow{4}{*}{$\mathrm{D}$} & Control & 40 & 0.35 & 29.1 & 12.5 & 16.6 & 48.3 & 3.80 \\
\hline & & Silicon & 41 & 0.36 & 29.2 & 12.6 & 16.6 & 48.4 & 3.80 \\
\hline & & Humic & 43 & 0.40 & 29.3 & 12.6 & 16.7 & 48.4 & 3.75 \\
\hline & & Silicon+Humic & 44 & 0.39 & 29.3 & 12.6 & 16.7 & 48.4 & 3.75 \\
\hline \multicolumn{3}{|c|}{ F test for Factor A } & $*$ & $*$ & Ns & Ns & Ns & Ns & Ns \\
\hline \multicolumn{3}{|c|}{ L.S.D 0.05 for Factor B } & 0.0675 & 0.0009 & Ns & Ns & Ns & Ns & Ns \\
\hline & & 3efore planting & 43 & 0.41 & 29.8 & 12.7 & 17.1 & 49.1 & 3.80 \\
\hline \multirow{8}{*}{ 홍 } & \multirow{4}{*}{$\mathrm{N}$} & Control & 43 & 0.40 & 29.8 & 12.7 & 17.1 & 49.1 & 3.80 \\
\hline & & Silicon & 43 & 0.41 & 29.8 & 12.8 & 17 & 49.1 & 3.80 \\
\hline & & Humic & 46 & 0.5 & 30.5 & 12.9 & 17.5 & 49.2 & 3.80 \\
\hline & & Silicon+Humic & 46 & 0.49 & 30.3 & 13 & 17.2 & 49.2 & 3.80 \\
\hline & \multirow{4}{*}{$\mathrm{D}$} & Control & 41 & 0.36 & 29.2 & 12.6 & 16.6 & 48.3 & 3.90 \\
\hline & & Silicon & 41 & 0.37 & 29.6 & 12.7 & 16.9 & 48.4 & 3.90 \\
\hline & & Humic & 42 & 0.42 & 30.0 & 12.8 & 17.2 & 48.5 & 3.85 \\
\hline & & Silicon+Humic & 42 & 0.43 & 29.9 & 12.8 & 17.1 & 48.5 & 3.80 \\
\hline \multirow{2}{*}{\multicolumn{3}{|c|}{$\begin{array}{c}\text { F test } \\
\text { L.S.D. for Factor B }\end{array}$}} & $*$ & $*$ & $\mathrm{Ns}$ & Ns & Ns & Ns & Ns \\
\hline & & & 0.1697 & 0.0012 & Ns & Ns & Ns & Ns & Ns \\
\hline
\end{tabular}

Factor A: Irrigation regime; Factor B: Treatment "humic acid, silicon and silicon + humic acid"
$\mathrm{N}=$ normal irrigation
$\mathrm{D}=$ water stress

Where Ns, and * means non-significant, and significant at 0.05 levels of probability, respectively. 
Table 7. Chemical analysis for soil samples under investigation.

\begin{tabular}{|c|c|c|c|c|c|c|c|c|c|c|c|c|}
\hline \multirow{2}{*}{ 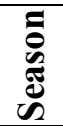 } & \multirow{2}{*}{\multicolumn{2}{|c|}{ Treatments }} & \multirow{2}{*}{$\underset{1: 2.5}{\text { pH }}$} & \multirow{2}{*}{$\begin{array}{c}\text { EC } \\
\text { ds } / m\end{array}$} & \multicolumn{4}{|c|}{ Cations me/L } & \multicolumn{4}{|c|}{ Anions me/L } \\
\hline & & & & & $\mathrm{Ca}^{2+}$ & $\mathrm{Mg}^{2+}$ & $\mathrm{Na}^{+}$ & $\mathrm{K}^{+}$ & $\mathrm{CO}_{3}{ }^{2-}$ & $\mathrm{HCO}_{3}^{-}$ & $\mathrm{Cl}^{-}$ & $\mathrm{SO}_{4}{ }^{2-}$ \\
\hline \multirow{9}{*}{$\widetilde{\sim}$} & & efore Planting & 7.68 & 1.02 & 3.1 & 2.8 & 4.7 & 1.1 & - & 0.4 & 8.2 & 4 \\
\hline & \multirow{4}{*}{$\mathrm{N}$} & Control & 7.68 & 1.06 & 3.2 & 2.9 & 4.8 & 1.1 & 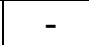 & 0.4 & 8.2 & 4 \\
\hline & & Silicon & 7.68 & 1.10 & 3.2 & 2.9 & 4. & 1. & & 0.4 & 8.2 & 4 \\
\hline & & Hun & 7.66 & 1.00 & 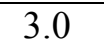 & 2.9 & 4. & 1 & & 0.4 & 0.1 & 4 \\
\hline & & Silicon+Hur & 7.67 & 1 & 3.2 & 2.9 & & & & 0.4 & 8.2 & 4 \\
\hline & \multirow{4}{*}{ D } & Control & 7.70 & 1.30 & 3.7 & 2.8 & 6. & 1.3 & & 0.7 & 8 & 4.3 \\
\hline & & Sili & 7.69 & 1.40 & 4.4 & 2. & 6. & 1.2 & & 0.5 & 8.5 & 5 \\
\hline & & Humic & 7.68 & 1 & 3.5 & 2.7 & 5. & 1. & & $0 .($ & 7.1 & 4.3 \\
\hline & & Silicon+Humic & 7.68 & 1.32 & 3.8 & 2.7 & 5.3 & 1.2 & & 0.8 & 7.0 & 4.1 \\
\hline \multicolumn{3}{|c|}{ F test for Factor A } & $\mathrm{Ns}$ & $*$ & $*$ & 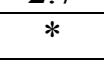 & 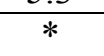 & 4 & & $*$ & 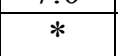 & $*$ \\
\hline \multicolumn{3}{|c|}{ L.S.D. 0.05 for Factor B } & Ns & 0.0074 & 0.0442 & 0.0101 & 0.0442 & 0.0276 & & 0.0018 & .0442 & 0.002 \\
\hline & \multicolumn{2}{|c|}{ Before Planting } & 7.67 & 1.20 & 3.5 & 2.3 & 5.1 & 1.1 & 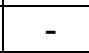 & 0.6 & 7.1 & 4.30 \\
\hline \multirow{8}{*}{ 홍 } & \multirow{4}{*}{$\mathrm{N}$} & Control & 7.67 & 120 & 3.5 & 2.3 & 5. & 1. & 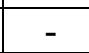 & 0.6 & 7.1 & 4.30 \\
\hline & & $\overline{\mathrm{S}} 1$ & 7.67 & & 3.2 & 2.8 & 6 & 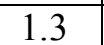 & - & 0.7 & 8 & 4.3 \\
\hline & & Hum & 7.65 & & 3.3 & 2.9 & 4. & 1. & - & 0.5 & 7.2 & 4 \\
\hline & & Silicon+Humic & 7.65 & 1 & 3.7 & 2.8 & 6. & 1. & - & 0.7 & 8 & 4.3 \\
\hline & \multirow{4}{*}{$\mathrm{D}$} & Control & 7.70 & 0 & 4.8 & 2.5 & 6. & 1 . & & 0.6 & 7.2 & 6.2 \\
\hline & & Silicon & 7.67 & 1.50 & 5 & 3.2 & 6.2 & 1. & & 0.6 & 8.2 & 6.2 \\
\hline & & Humic & 7.67 & 1.25 & 3.6 & 2.4 & 5.3 & 1.2 & - & 0.6 & 7.3 & 4.6 \\
\hline & & Silicon+Humic & 7.67 & 1.46 & 4.7 & 2.5 & 6.2 & 1.3 & 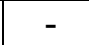 & 0.7 & 8.5 & 5.3 \\
\hline \multicolumn{3}{|c|}{ F test for Factor A } & Ns & $*$ & $*$ & $*$ & $*$ & $*$ & & * & $*$ & * \\
\hline \multicolumn{3}{|c|}{ L.S.D. 0.05 for Factor B } & Ns & 0.0043 & .072 & .0156 & 0.04 & .0068 & & 0.0015 & 0.0442 & 0.0442 \\
\hline
\end{tabular}

Factor A: Irrigation regime; Factor B: Treatment "humic acid, silicon and silicon + humic acid"
$\mathrm{N}=$ normal irrigation
$\mathrm{D}=$ water stress

Where Ns, and * means non-significant, and significant at 0.05 levels of probability, respectively

\section{References}

Abd El-Kareem, Thanaa, El-Hussin, and Ahmed G.G. (2013). Evaluation of Four New Bread Wheat (Triticum aestivum L.) Cultivars in Sandy Soils under Different Irrigation Regimes and Nitrogen Fertilizer Rates for Yield and Its Components Alex. J. Agric. Res. 58:3, pp. 241-250.

Abdrabbo, M.A.A., Hashem F.A. and Abou-Hadid A. F. (2016). Irrigation requirements for some bread wheat cultivars in relation to planting dates. J. Agric. Sci. Res. Vol. 3, Issue 1, 23-40.

Acevedo, E., Harris, H. and Cooper P.J.M., (1991). Crop architecture and water use efficiency in Mediterranean environments. In H. Harris, P.J.M. Cooper and M. Pala, eds. Soil and Crop Management for Improved Water Use Efficiency in Rainfed Areas, p.106118. ICARDA.

Ahmad, F., Rahmatullah Aziz T., Maqsood M.A., Tahir and Kanwal M.A., (2007). Effect of silicon application on wheat (Triticum aestivum L.) growth under water deficiency stress. Emir J Food Agric 19:01-07.

Akinremi, O.O., Janzen H.H., Lemke R.L. and Larney F.J. (2000). Response of canola, wheat and green 
beans to leonardite additions. Canadian J. Soil Sci. 80: 437-443

Ali, A., M. Tahir, M. Amin, S.M.A. Basra, M. Maqbool, and D.J. Lee, (2013). Silicon induced stress tolerance in wheat hydroponically grown under water deficit conditions. Bulg. J. Agric. Sci., 19: 951957.

Asal, M.W., Badr E.A., Ibrahim O.M. and Ghalab E.G. (2015). Can humic acid replace part of the applied mineral fertilizers? A study on two wheat cultivars grown under calcareous soil conditions. International Journal of ChemTech Research, Vol.8, No.9, pp 20-26.

Black, C.A. (1965). Methods of soil analysis. Part I, American Society of Agronomy. Madison, Wisconsin, USA. 1572 p.

Bukhari, M., Ashraf M.Y., Ahmad R., Waraich E.A. and Hameed $M$. (2015). Improving drought tolerance potential in wheat through exogenous silicon supply. Pak. J. Bot., 47: 1641-1648.

Canellas, L.P., Olivares F.L., Aguiar N.O., Jones D.L., Nebbioso A., P Mazzei. and A Piccolo., (2015). Humic and fulvic acids as bio stimulants in horticulture. Sci. Hort. 196, 15-27.

Chen, Y., Magen H. and Clapp C.E., (2001). Plant growth stimulations by humic substances and their complexes with iron. Proc. International Fertilizer Society, York, UK. 470:1-14.

Cihlář Zdeněk, Vojtová Lucy, Conte Pellegrino, Nasir Saqib, Kučerík Jiří (2014). Hydration and water holding properties of cross-linked lignite humic acids, Geoderma 230 231, 151-160.

Cimrin, K.M. and Yilmaz I. (2005). Humic acid applications to lettuce do not improve yield but do improve phosphorus availability. Ac- ta Agriculturae Scandinavica, Section B, Soil and Plant Science, 55: 58-63.

Epstein, E. (1999). Silicon. Ann. Rev. Plant Physiol. Plant Mol. Biol. 50, 641-664.

Gee, G.W. and Orr D. (1994). Particle size analysis. In methods of soil analysis part 4. Physical methods. Soil science Amer. Book Series 5. Edited by Dome, J.H. and Topp, G.C. SSSA Madison WI.2002:255293.

Geng, S.M., Yan D.H., Zhang T.X., B Weng.S., Zhang Z.B., Qin T.L. (2015). Effects of drought stress on agriculture soil. Natural Hazards. 75 (2), 1997-2011.

Glaser, B., Lehmann J. and Zech W. (2002). Ameliorating physical and chemical properties of 268 highly weathered soils in the tropics with charcoal: a review, Biology and Fertility of Soils, 269 35, 219-230.

Gomez, K.A. and Gomez A.A. (1984). Statistical procedures for agricultural research $\left(2^{\text {nd }}\right.$ ed. $)$. John wiley and sons, New York, 680p.

Gong, H.J., Chen K.M., Chen G.C., Wang S.M. and Zhang C.L. (2003). Effect of silicon on growth of wheat under drought. J. Plant Nutr. 26(5):1055-1063.

Hattori, T., Inanaga S., Araki H., An P., Mortia S., Luxova M. and Lux A. (2005). Application of silicon enhanced drought tolerance in Sorghum bicolor. Physiolgia Plantarum. 123: 459-466.

Hesse, P.R . (1971). A textbook on soil analysis. John Murray, London.

Ibrahim, S.M. and Goh T.B. (2004). Changes in macroaggregation and associated characteristics in mine tailings amended with humic substances. Comm. Soil Sc. Plant Anal. 35, 1905-1922. 
Jackson M. (1973). soil chemical analysis, Prentice-Hall, Inc., Englewood Cliffs, N. J.

Kandil A.A., Sharief A.E.M., Seadh S.E. and Altai D.S.K (2016). Role of humic acid and amino acids in limiting loss of nitrogen fertilizer and increasing productivity of some wheat cultivars grown under newly reclaimed sandy soil. Int. J. Adv. Res. Biol. Sci, 3 (4):123-136.

Kang S., Zhang L., Y Liang., Hu X., Cai $\mathrm{H}$. and $\mathrm{Gu}$ B. (2002). Effects of limited irrigation on yield and water use efficiency of winter wheat in the Loess Plateau of China. Agric. Water Manage., 55, 203-216.

Karmollachaab, A., Gharineg M.H., Bakhshandeh M., Moradi M., and Fathi G. (2014). Effect of Silicon application on physiological characteristic and growth of wheat (Triticum aestivum L.) under drought stress conditions. Agroecology 5(4): 430- 442.

Khan, R., Rashid A., Khan, M.S. and Ozturk, E. (2010). Impact of humic acid and chemical fertilizer application on growth and grain yield of rainfed wheat (Triticum aestivum L.). Pakistan J. of Agri. Res. 23(34), 113-121.

Kobata, T., Palta J.A. and Turner N.C., (1992). Rate of development of post anthesis water deficits and grain filling of spring wheat. Crop Sci., 32: 1238-1242.

Kumar, D., Singh A.P., Raha P., Rakshit A., Singh C.M. and Kishor P. (2013). Potassium Humate: A Potential Soil Conditioner and Plant Growth Promoter. Inter. J of Agri., Env. and Biotech., 6(3): 441-446.

Lal, S., D.L. Bagdi, B.L. Kakralya, Jat, M.L., and Sharma, P.C. (2013). Role of brassinolide in alleviating the adverse effect of drought stress on physiology, growth and yield of green gram (Vigna radiatal.) genotypes, Legume Res., 36, 359-363.

Magdoff, Fred and Harold van Es, (2009). Building Soils for Better Crops Sustainable Soil Management, $3^{\text {rd }}$ ed, Handbook series, Sustainable Agri. Res. and Edu. Prog., 294.

Maghsoudi, K., Emam Y., and Ashraf, M., (2016). Foliar application of silicon at different growth stages alters growth and yield of selected wheat cultivars. Jour. of Plant Nutr., 39(8), 1194-1203.

Mekkei, M.E. and El Haggan, A.M. (2014). Effect of Different Irrigation Regimes on Grain Yield and Quality of Some Egyptian Bread Wheat Cultivars. JAAS. Jour. 2(9): 275-282.

Melo, S. P., Korndorfer, G.H., Korndorfer, C.M., Lana, R.M.Q. and Santan, D.G. (2003). Silicon accumulation and water deficient tolerance in grasses. Scientia Agricola. 60:755-759.

Mohamed, A.A.E. (2013). Effect of water stress on morphological, physiological and productivity traits of wheat. Ph.D. Thesis, Faculty of Agric., Cairo Univ.

Moustafa, M.A., Boersma, L., and Kronstad, W.E. (1996). Response of four spring wheat cultivars to drought stress. Crop Sci., 36: 982986.

Nelson, D.W and Somners, L.E. (1982). Total carbon and organic matter. In Page, AL., Miller, R.H., Keenu, D.R (eds). Methods of soil analysis. Part $22^{\text {nd }}$ edn. Agron. Monograph No 9 USA and SSSA Madison, 1:539-579.

Said, M.T. and Abd El-Moneem, A.M.A. (2016). Response of Two Bread Wheat Cultivars to Foliar Spray by Salicylic and Ascorbic Acids under Water Stress Condi- 
tions. Assiut J. Agric. Sci., (47) No. (6-2) (391-404).

Saini, H.S. and Westgate, M.E. (2000). Reproductive development in grain crops during drought. Advances in Agron. 68,59-96.

Savant, N.K., Snyder, G.H., and Datnoff, L.E. (1997). Silicon management and sustainable rice production. Adv. Agron. 58, 151-199.

Shahryari, R, and Mollasadeghi, V. (2011). Increasing of wheat grain Yield by use of a humic fertilizer. Adv. Env. Bio., 5(3): 516-518.

Silva, O.N., Lobato, A.K., Avila, F.W., Costa, L., Oliveira, F., Santos, B.G., Martins, A.P., Lemos, R., Pinho, J., Medeiros, M.B., Cardoso, M., and Andrade, I.P. (2012). Silicon-induced increase in chlorophyll is modulated by the leaf water potential in two waterdeficient tomato cultivars. Plant Soil Env. 58:481-486.

Singh, R.B., Chauhna, C.P.S. and Minhas, P.S. (2009). Water production functions of wheat irrigation with saline and alkali waters using double line source sprinkler system Agric. Water Management, 96(5): 736-744.

Thalooth, Manal, F.M., Amal, A.T, Ahmed, G., Mohamed, Magda H. and Elewa, T.A. (2016). Evaluation of the effect of chemical fertilizer and humic Acid on yield and yield components of wheat plants (Triticum aestivum L.) grown under newly reclaimed sandy soil. Int. Jour. of Chem. Tech. Res. 9 (8): 154-161. 
تأثير استخدام السيليكون وحمض الهيوميك تحت ظروف الإجهاد المائي على بعض أصناف قمح الخبز وبعض خصائص التربة الاجية

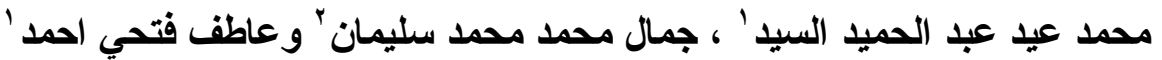

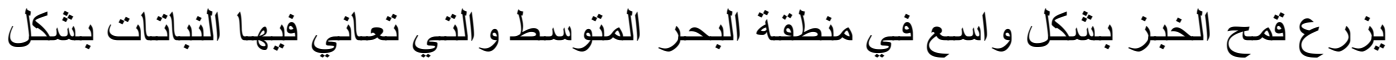

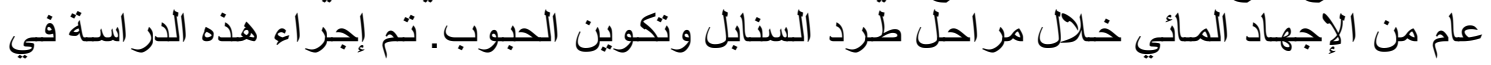

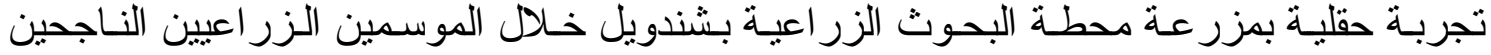

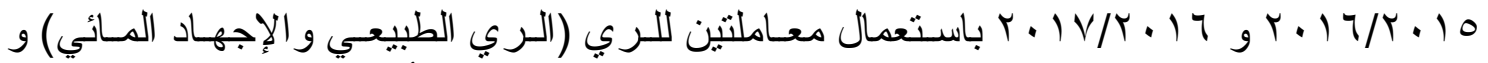

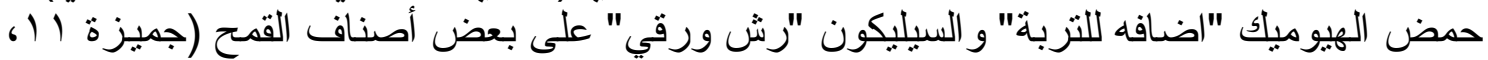

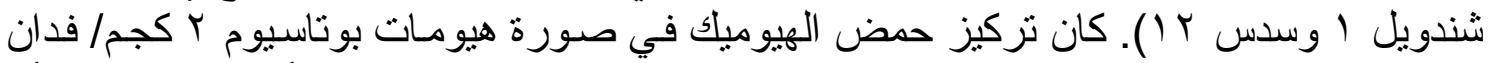

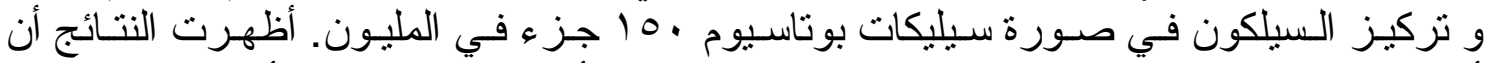

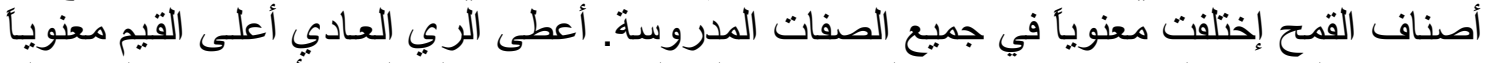

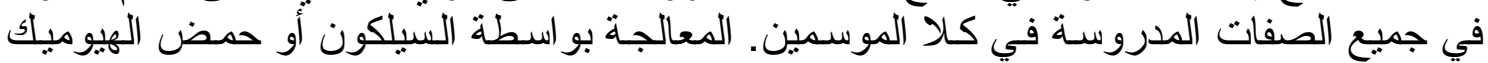

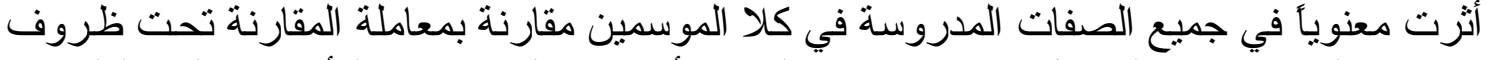

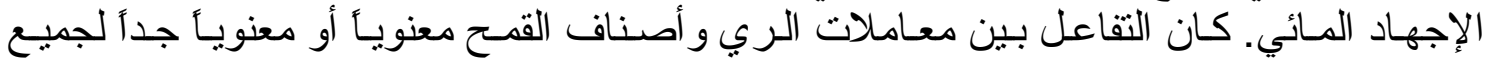

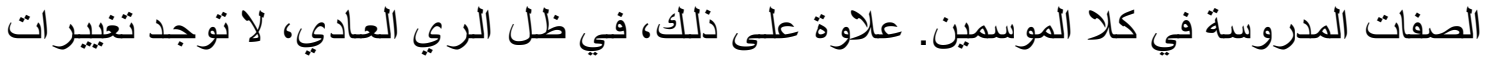

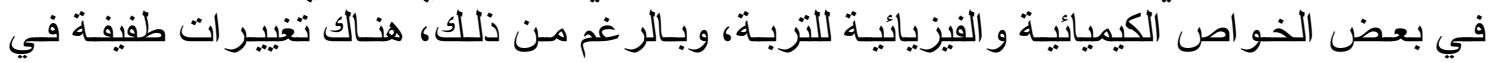

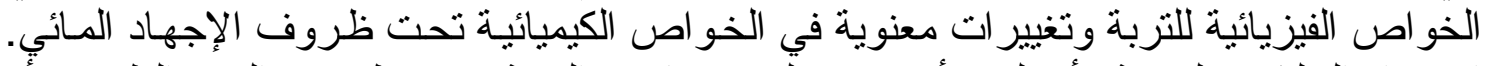

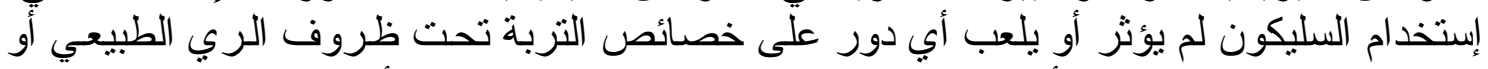

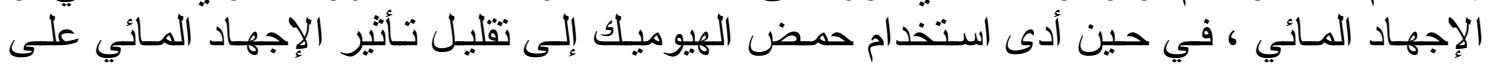
خصائص التربة. 